\title{
Towards a Dynamic (Schumpeterian) Welfare Economics
}

\section{Wilfred Dolfsma}

\begin{tabular}{|l|l|}
\hline \multicolumn{2}{|l|}{ ERIM REPORT SERIES RESEARCH IN MANAGEMENT } \\
\hline ERIM Report Series reference number & ERS-2004-026-ORG \\
\hline Publication & April 2004 \\
\hline Number of pages & 27 \\
\hline Email address corresponding author & w.dolfsma@fbk.eur.nl \\
\hline Address & Erasmus Research Institute of Management (ERIM) \\
& Rotterdam School of Management / Rotterdam School of Economics \\
& Erasmus Universiteit Rotterdam \\
& P.O.Box 1738 \\
& 3000 DR Rotterdam, The Netherlands \\
& Phone: +31 10 408 1182 \\
& Fax: $\quad+31104089640$ \\
& Email: info@erim.eur.nl \\
& Internet: $\quad$ www.erim.eur.nl \\
\hline
\end{tabular}

Bibliographic data and classifications of all the ERIM reports are also available on the ERIM website: www.erim.eur.nl 


\title{
ERASMUS RESEARCH INSTITUTE OF MANAGEMENT
}

\author{
REPORT SERIES \\ RESEARCH IN MANAGEMENT
}

\begin{tabular}{|c|c|c|}
\hline \multicolumn{3}{|c|}{ BIBLIOGRAPHIC DATA AND CLASSIFICATIONS } \\
\hline Abstract & \multicolumn{2}{|c|}{$\begin{array}{l}\text { For an economy where knowledge plays an increasingly important role in shaping its dynamics, } \\
\text { economics needs a dynamic (Schumpeterian) welfare theory. This paper sketches the role of } \\
\text { knowledge in an economy and argues that a static Paretian welfare economics is inadequate, } \\
\text { or at least needs to be supplemented. As suggested by the work of Schumpeter, a dynamic } \\
\text { welfare economics acknowledges the role of knowledge. In a dynamic welfare economics, I } \\
\text { suggest, different costs of communication are central, indicating that knowledge may not be } \\
\text { readily diffused or exchanged. Recent developments in Intellectual Property Right (IPR) law are } \\
\text { evaluated to determine the extent to which they affect communication costs and thus future } \\
\text { economic welfare. }\end{array}$} \\
\hline \multirow{3}{*}{$\begin{array}{l}\text { Library of Congress } \\
\text { Classification } \\
\text { (LCC) }\end{array}$} & $5001-6182$ & Business \\
\hline & $5546-5548.6$ & Office Organization and Management \\
\hline & HB99.3 & Welfare economics \\
\hline \multirow{3}{*}{$\begin{array}{l}\text { Journal of Economic } \\
\text { Literature } \\
\text { (JEL) }\end{array}$} & M & Business Administration and Business Economics \\
\hline & $\begin{array}{l}\text { M } 10 \\
\mathrm{~L} 2\end{array}$ & $\begin{array}{l}\text { Business Administration: general } \\
\text { Firm Objectives, Organization and Behaviour }\end{array}$ \\
\hline & D6 & Economic Welfare \\
\hline \multirow{3}{*}{$\begin{array}{l}\text { European Business Schools } \\
\text { Library Group } \\
\text { (EBSLG) }\end{array}$} & $85 \mathrm{~A}$ & Business General \\
\hline & $\begin{array}{l}100 B \\
240 B\end{array}$ & $\begin{array}{l}\text { Organization Theory (general) } \\
\text { Information Systems Management }\end{array}$ \\
\hline & $170 \mathrm{G}$ & Welfare economics \\
\hline \multicolumn{3}{|c|}{ Gemeenschappelijke Onderwerpsontsluiting (GOO) } \\
\hline \multirow[t]{3}{*}{ Classification GOO } & 85.00 & Bedrijfskunde, Organisatiekunde: algemeen \\
\hline & $\begin{array}{l}85.05 \\
85.08\end{array}$ & $\begin{array}{l}\text { Management organisatie: algemeen } \\
\text { Organisatiesociologie, organisatiepsychologie }\end{array}$ \\
\hline & 83.12 & Macro-economie \\
\hline \multirow[t]{3}{*}{ Keywords GOO } & \multicolumn{2}{|c|}{ Bedrijfskunde / Bedrijfseconomie } \\
\hline & \multicolumn{2}{|c|}{ Organisatieleer, informatietechnologie, prestatiebeoordeling } \\
\hline & \multicolumn{2}{|c|}{ Economie, kennis, welvaartseconomie, intellectueel eigendom, communicatie, } \\
\hline Free keywords & \multicolumn{2}{|c|}{ Knowledge economy, welfare theory, IPR, communication, communication costs } \\
\hline
\end{tabular}




\title{
Towards a Dynamic (Schumpeterian) Welfare Economics ${ }^{1}$
}

\author{
Wilfred Dolfsma ${ }^{2}$ \\ Erasmus University Rotterdam \& Maastricht University (MERIT)
}

Abstract: $\quad$ For an economy where knowledge plays an increasingly important role in shaping its dynamics, economics needs a dynamic (Schumpeterian) welfare theory. This paper sketches the role of knowledge in an economy and argues that a static Paretian welfare economics is inadequate, or at least needs to be supplemented. As suggested by the work of Schumpeter, a dynamic welfare economics acknowledges the role of knowledge. In a dynamic welfare economics, I suggest, different costs of communication are central, indicating that knowledge may not be readily diffused or exchanged. Recent developments in Intellectual Property Right (IPR) law are evaluated to determine the extent to which they affect communication costs and thus future economic welfare.

Keywords: knowledge economy, welfare theory, IPR, communication, communication costs

\footnotetext{
${ }^{1}$ I would like to thank Mark Blaug and participants in an ECIS (Eindhoven) seminar for helpful discussions; responsibilities for the views expressed and the faults remaining are the author's alone.

${ }^{2}$ Correspondence: Erasmus University Rotterdam - FBK, PO Box 1738, 3000 DR Rotterdam, the Netherlands, ph.+31-10-4081948, email w.dolfsma@fbk.eur.nl
} 


\section{Towards a Dynamic (Schumpeterian) Welfare}

\section{Economics}

In chapter 17 of his Capitalism, Socialism and Democracy Schumpeter (1943, p. 190, italics in original) has introduced some fundaments for a dynamic welfare economics. One passage is especially worth noting:

\footnotetext{
"we shall call that system relatively more efficient which we see reason to expect would in the long run produce the larger stream of consumers' goods per equal unit of time"
}

In this paper I will start from the perspective that the newly emerging reality of our economies today is that they are knowledge economies (OECD 1996). This is recognized in diverse strands of thought in the economics discipline after the puzzling findings in the Growth Accounting literature (e.g. Denison 1967). Romer $(1987,1993)$ has been developing ideas about how knowledge impacts on economic growth, better known as New Growth Theory. The work of Baumol (2002) relates to this. Studying a dynamic, knowledge-based economy requires that a conceptual understanding of knowledge and its role in society is developed and used in economics. The first section discusses this in some measure. My argument is that a knowledge-based economy would also need a different welfare economics that would allow one to evaluate developments in society or government policy. A second section will give an outline of the welfare economic perspective that is now mostly adhered to, that following Pareto. A dynamic, Schumpeterian welfare economics would emphasize the development of knowledge and its use in the economy. Relatedly, the argument in favor of competition in the market and dynamic efficiency is emphatically not based on Paretian considerations of perfect competition (Baumol 2002, Blaug 2001, Mokyr 2002, Nelson 1981, 2004). The third section suggests some elements for a welfare economic perspective. A much debated policy issue that is very relevant for the knowledge-based economy is subsequently looked at to evaluate some measures that governments are currently 
implementing. How would a dynamic welfare economics evaluate changes in the system of intellectual property right law?

\section{Knowledge and the Dynamics of an Economy}

In recent years it has come to be acknowledged that development of new knowledge is an important source of dynamics for an economy. Knowledge is, however, a very much heterogeneous entity and so using notions such as 'capital' to better come to grips with it have little metaphorical value (Dolfsma 2001).

To paraphrase Isaac Newton, knowledge is developed by people who could see further because they stand on the shoulders of giants. This, of course, is a well-established observation about the cumulative nature of development of knowledge, but at the same time was a derisive remark against Newton's opponent in a discussion about the nature of gravity in a letter in 1776 to Robert Hooke. Hooke was a short man who walked bended forward. Knowledge develops as much in a social context as it is cumulative. There are at least two other characteristics of knowledge that entail that in assessing welfare effects, one needs a perspective that takes dynamic processes by which knowledge develops into account. The development of knowledge involves tacit dimensions, and requires coding and decoding. These four characteristics are at work at the individual, the organizational, ${ }^{3}$ the regional ${ }^{4}$ as well as at a societal level. As at the latter three the knowledge development essentially involves individuals too, I will discuss this at some length. In addition, as the welfare perspective introduced below will take social welfare of a community (society) as a touch-stone, the implications of the characteristics of knowledge development for the dynamics at the societal level are discussed as well.

Knowledge differs from information (data) in that it needs to be interpreted to make sense of. Michael Polanyi has developed a theory of knowledge acquisition that should also be of interest to economists (see Scitovsky 1977). Polanyi (1983: 7) argues that (tacit) knowledge is acquired in a process he calls 'subception.' Any piece of information to be transplanted from one person to somebody else is 'recepted' (ibid.: 5) by this other person and integrated or 'subsumed' into a larger framework of

\footnotetext{
${ }^{3}$ See Hansen (1999), for instance, and similar research.

${ }^{4}$ See Van der Panne and Dolfsma (2003), and references therein.
} 
knowledge in which meaning is given to this new piece of information (ibid., p. 19). To the extent that information is subsumed (and it has to be subsumed if it is to have any meaning) into a larger framework of knowledge, it is interiorized (ibid., p. 29), as it were, to become a part of the body (cf. Douglas 1986, p. 13). From this it follows that man cannot always accurately state what it is that he knows about a certain topic. Such knowledge is typically "fraught with further intimations of an indeterminate range" (Polanyi 1983, p. 23), constituting what might be called a "mountain of experience'(Dolfsma 2002). Where knowledge relevant to the particular subject becomes irrelevant is difficult to ascertain; there is a difficulty of separating relevant from irrelevant knowledge. Veblen (1961b, p. 74) goes even farther than this in asserting that man is "a coherent structure of propensities and habits" (Cf. Dolfsma 2002). Prior knowledge is thus needed to acquire knowledge, but additional information does not necessarily increase one's knowledge: there are costs involved in storing knowledge. Knowledge building is not automatic, but involves being able to discern patterns. Despite having the same information, people might hold different views of the world, which can make communication difficult (costly) as decoding needs to occur. In addition to any decoding that might be necessary, communication (transfer of knowledge) is costly in itself as well. Separating the knowledge one needs to communicate can be costly, while the means used to communicate can also involve costs for the sender. Such a view of knowledge and information differs from the one generally subscribed to in economics. Here, the idea is that additional knowledge will reduce noise (see Denzau \& North 1994). Persistently diverging learning paths, such as those between A and B in Figure 1 are excluded.

$<$ Figure 1 about here $>$

In a recent book Joel Mokyr (2002) has argued that the industrial revolutions need to be explained by the development, but mostly by the use of new knowledge. There are a number of noteworthy observations Mokyr makes about the role of knowledge for economic development. A first one is that there have been striking macro inventions before the first Industrial Revolution in England. None of these inventions gave rise to sustained economic growth, however. Figure 2 is a framework that Mokyr suggests to understand the role of knowledge in the economy and in society. Propositional knowledge is 
knowledge about 'how to manipulate nature' (Mokyr 2002); this includes more than what we would now call academic knowledge. Savants posses this type of knowledge. Prescriptive knowledge contains concrete directions about how to solve a particular problem; it is useful knowledge possessed by fabricants. Developments in both types of knowledge may stimulate one another. Mokyr explains this by pointing out that the knowledge base of economies (propositional knowledge) then was too limited, the knowledge available was not 'tight' enough to convince people to invest in the creation of new products or processes based on prepositional knowledge.

A second observation is that it can be considered a coincidence, in a way, that England around 1780 was the first country where sustained economic growth based on the use of newly developed knowledge could be observed. England was by no means the most technologically advanced country, and indeed it used knowledge developed in countries such as France extensively. Mokyr points to the institutions of English society that lowered the costs of communication about new knowledge. The result was that knowledge was much more readily exchanged among savants, among fabricants, and between these two groups. Thus, new knowledges more easily created, and existing knowledge is put to good use faster, even if the knowledge would be of a tacit nature (Cowan et al. 2000).

Communication then, in Mokyr's argument, will both broaden and tighten the knowledge base of prepositional knowledge, and stimulate the development of techniques (prescriptive knowledge) that find an immediate application in society and stimulate economic activity.

$<$ Figure 2 about here $>$

Knowledge may affect a firm's processes in other ways too. Knowledge can be recognized as immaterial assets in a firm's financial accounts, acknowledging its importance as productive factor. Introducing knowledge in a firm's financial accounts allows it to use it as collateral in capital markets. Soon (in 2005) to be implemented rules in Europe, following the American example, clarify this hitherto murky situation (Lev 2001). Intellectual property (knowledge made exclusive) also plays an increasingly important role in strategic manoeuvring between firms (Lev, 2001; Shapiro \& Varian, 1999; Granstrand, 1999). IPRs may make a firm an inevitable player in a network, and it may allow a 
firm to exclude others from a network. This does not only hold for IPRs, but also for trade secrets and tacit knowledge, as long as access or use of such knowledge can be restricted. Economists have argued that agents need incentives to be persuaded to develop new knowledge. If such incentives - primarily in the case of a system of intellectual property right (IPR) laws - would not exist, there would be an undersupply of new knowledge and basic knowledge in particular (Nelson 1959). This argument is made both in case of patents, as well as in the case of copyrights (Landes \& Posner 1989). Without incentives, agents would not develop new knowledge, or would not make it publicly available.

Nevertheless, it is known that firms do engage in fundamental research and have good reasons for doing so (Rosenberg 1990), even when they know they cannot receive a patent to legally prevent others from commercially exploit the knowledge. In addition, not all firms find it worthwhile to apply for a patent (Arundel 2001; Nelson et al. 1987). Increasingly the arguments legitimising a system of IPRs have shifted to emphasizing the need for these institutions to offer protection so that investments in production facilities can be recouped before copycats who had to spend less in developing a product than the innovator enter the market (Hettinger 1989).

\section{Paretian Welfare Economics}

Historian of economic thought Mark Blaug (2001, p.39) has lamented on several occasions the "replacement of the process conception of competition by an end-state conception [which] drained the idea of competition of all behavioural content", where not the existence of an equilibrium but rather the stability of that equilibrium state is analyzed (cf. Vickers 1995). Blaug traces the origins of this approach to Cournot, Walras, and blames Samuelson, Hicks and Robbins for establishing it as the mainstream.

Every first year student of economics is presented with the picture of perfect competition between large groups of suppliers and consumers of homogenous products. The Pareto optimum welfare conditions to attain a first-best situation are well known and need not be reproduced here. The thinking about welfare economics in the 1930s up to the 1950s has moved from discussing cardinal utility functions, to the Hicks-Kaldor compensation criteria, to the Lipsey \& Lancaster second-best theorem, 
and to Arrow \& Debreu's impossibility theorem. I will not discuss this development in the economics literature at length.

$<$ Figures 3 and 4 about here $>$

Central assumptions in Paretian welfare economics are, among others, three postulates: "consumer sovereignty, individualism in social choice, and unanimity" (Blaug 1980, p.148). Every individual (agent) is the best judge of his own welfare, social welfare is defined only in terms of the welfare of individuals and the welfare of individuals may not be compared. These, together with assumptions about parties' objective functions and motivation (Profit and Utility maximization) allow one, for the analysis for instance of a world where two goods (A and B) are offered to determine the optimum situation at the point of Tangency in Figure 3 where marginal costs of production equals marginal utility. At the same time, the relative price ratio between the two goods equals marginal utility, constituting a Pareto-optimal situation. Changes in either the Supply or the Demand curve in Figure 4, for whatever reason, will be evaluated in terms of welfare triangles. In the figure, a movement of the Supply curve is shown (from S to S'), leading to a 'deadweight welfare loss' of the size of triangle $\mathrm{ABC}$.

To date, Paretian welfare theory still dominates, while a characterization made in a 1960 survey of welfare economics still holds as well (Mishan 1960, p.198):

\footnotetext{
"No growth or innovation takes place, no uncertainty exists and individual tastes remain unaltered. In addition, the working population is fixed and is, in some sense, fully employed. Within this framework it is further assumed that individual behaviour is consistent, and (...) that the individual is the best judge of his own wants."
}

For my purposes, the first part of the quote is especially noteworthy. As Paul Romer (1994) argues, however, the conditions that are here placed under the c.p. clause are far from rare conditions. The kind of analysis that needs to posit these assumptions may thus not be as relevant as one might assume: "to 
keep things simple, set aside the niggling disputes about consumer surplus as a welfare measure" is what he suggests (Romer 1994, p.15; cf. Blaug 2001, p.47).

\section{A Dynamic Welfare Perspective}

A more appropriate (additional) welfare theory would be acknowledging the dynamics in today's knowledge economies. The comparative static foundations of a Paretian approach are less appropriate in such circumstances. Indeed, as Tyler Cowen (2000) has argued, there have been more attempts at suggesting different theories to the established welfare economics of Vilfredo Pareto. Cowen (2000, p.xiii) distinguishes "three dominant yet incompatible strands": ordinalist Paretian welfare theory, applied cost-benefit analysis used in practical policy, and cardinalism of which Amartya Sen is a representative. The latter "returns to the purely theoretical realm but rejects Paretianism"; it "is less systematic and unified than the other two strands".

The public interest in the creation of new knowledge has been long established, mainly due in more recent decades to Richard Nelson $(1959,1990)$. In a dynamic economy, a static approach to welfare, emphasizing the end-state kind of competition is not very appropriate, however. Thus, "welfare loss triangles are admitted and downplayed" as Nelson (1981, p.106) has expressed it, following Schumpeter (1942). A welfare perspective emphasizing the dynamics in an economy will need to combine insights from a diverse set of related fields as such a perspective has not been developed to date (cf. Mokyr 2002, pp.21-27).

Schumpeter (1942, especially Chapter 17) indicates that the effects of choices made by private or public parties should (also) be evaluated in terms of their long-term effects - which alternative leads to the most attractive outcome in the future? Schumpeter seems to indicate that both measurable effects in the market as well as more immeasurable effects inside and outside of the market should be taken into consideration, although he is not very clear about how to develop these ideas into more operational terms. In line with Schumpeter's work, and prompted by a number of other scholars, I would suggest that 'communication' between agents plays an important role in shaping the processes through which an economy evolves from one stage to the next. To be more concrete, it would seem that there is a positive 
association between the ease with which communication may occur and economic development (see, e.g., Dudley 1999, Mokyr 2002).

In this contribution a main starting point will be to use a Cobb-Douglass type function for the production of knowledge. The use of this kind of function to model the production of knowledge is far from unique (Audretsch 1998, Dudley 1999), despite the use of production functions being questioned in general (Shaikh 1990) and in part due to the failure of the efforts at growth accounting (Denisof 1967). It starts from the idea that communication between parties can be more or less difficult, and that these difficulties can be translated into costs. The extent to which communication is difficult (costly) relates directly to the technology used, as well as to the established (cultural) mores about communication (cf. Mokyr 2002, Nelson 1990), as well as to more formal institutions. The costs can be direct or more mediated, and the effects are both on levels of welfare as on the ways organizations take shape (Milgrom \& Roberts 1988). Certainly when "more than 60 percent of the labor force in the United States is engaged in activities in the 'information sector' of the economy" (Baumol 2002, p.2) it is important to analyze the creation of new information and knowledge and its effects on the economy and its rate of growth.

In line with what Dudley (1999) suggests, three kinds of costs are related to communication the level of the costs involved determines the kind of communication that one may expect. ${ }^{5}$ One may distinguish Storage, Decoding and Transmission costs of communication. ${ }^{6}$ In a way, communication is an input that would lead to the 'output' in newly used and created knowledge. As it can often only be determined ex post if the knowledge involved signifies an incremental or a radical development, the discussion here applies to both these situations. ${ }^{7}$ When all of these costs are high, no communication occurs. ${ }^{8}$ When transmission costs are low but the others remain high, communication will be centralized, much as Figure 5a presents. As Storage costs decrease, like in Figure 5b, a decentralized communication structure emerges. When finally decoding costs are low, a distributed kind of

\footnotetext{
${ }^{5}$ Casson (1997, p.279) argues that transaction costs are a special case of communication costs. His is a plausible argument that needs to be pursued further, but will not be undertaken here.

${ }^{6}$ Mokyr (2002) seems to lump these together in his category of 'access costs'.

${ }^{7}$ In addition, as Levinthal (1998) has argued, technologies (knowledge) are often perceived as radically new when introduced in a certain context (community) from another context where it had been developing incrementally.

${ }^{8}$ For the sake of clarity, I assume that communication costs is a binary variable; it is either 'high' or 'low'.
} 
communication will be observed (Figure 5c). The suggested sequence for decreases in these

communication costs seems to match with what may be observed when one considers developments in the use of techniques involved in communication. Table 1 summarizes this discussion. Communication that is distributed (Figure 5c) is to be preferred from the position of the public interest, as knowledge and information is exchanged most readily and conditions for economic and societal development are most conducive.

$<$ Figure 5 about here $>$

The basic insight that centralization of communication raises costs and is not beneficial for society was also argued for by Nelson (1981, p.101): "the argument that centralization imposes high information and calculation costs carries considerable weight in a dynamic context". Indeed, for him it is a central argument for favoring capitalism over socialism, as it was for Hayek too. This view contrasts with "the standard theoretical analysis [which] implies that only zero spillovers [of knowledge] are compatible with optimality in innovative activity" (Baumol 2002, p.121). Rather, extensive dissemination of new knowledge benefits society, and it is of course this truth that is one fundament for the system of Intellectual Property Rights may be the most important. In exchange for a temporary exclusive right to use of newly developed knowledge, a party is to make this knowledge publicly available in order for others to build on it. Many firms even consider it directly beneficial for themselves to disseminate their newly developed knowledge (Baumol 2002, p.73), for instance because network effects can kick in more readily (Shapiro \& Varian 1999). It is for this reason that firms cluster geographically (Saxenian 1994), especially firms in high-tech sectors this should be considered a causal link (Van der Panne \& Dolfsma 2003).

$<$ Table 1 about here $>$

Pace Dudley (1999) one could include the three different communication costs in a Cobb-Douglass production function in order to assess the effects of changes in communication costs for economic 
welfare (equation 1). The main purpose of this production function is to evaluate changes in communication costs in terms of their effect on social welfare, and less so to study the affect of the absolute size of these costs. For my discussion here issues of returns to scale are irrelevant. A CobbDouglas production function makes most sense when the analysis is at an aggregate level, while there is also support for the use of this function at a disaggregate level (e.g., Gurbaxani et al. 2000). Given the nature of the exogenous variables involved, there is no point in assuming constant elasticities of substitution and hence adopt a CES production function. The Cobb Douglass production function is the most readily interpretable production function and is used most often in the literature (cf. Audretsch 1998). The suggested Cobb-Douglass production function primarily provides a heuristic tool here.

Nonetheless, it seems plausible to assume that total output, $q$, increases as a given population exchanges its information more readily. At any moment $(\mathrm{t})$, a community of size $(n)^{9}$ will experience a social welfare (q) generated by communication that can be represented as:

$$
\mathrm{q}_{\mathrm{t}}=\mathrm{A}\left(\begin{array}{l}
\mathrm{n}_{\mathrm{t}} \\
- \\
\mathrm{s}_{\mathrm{t}}
\end{array}\right)^{\alpha}\left(\begin{array}{l}
1 \\
-\mathrm{tr}_{\mathrm{t}}
\end{array}\right)^{\beta}\left(\begin{array}{l}
\mathrm{n}_{\mathrm{t}}-1 \\
\left.\frac{\mathrm{d}_{\mathrm{t}}}{}\right)^{\gamma}
\end{array}\right.
$$

Where:

$0<\alpha, \beta$, en $\gamma<1$,

$\mathrm{n}>>1$, and

$\mathrm{s}_{\mathrm{t}}, \mathrm{tr}_{\mathrm{t}}$, and $\mathrm{d}_{\mathrm{t}}>0{ }^{10}$

In this function A is the well-known efficiency parameter. The concrete shape of the production function makes economic sense. A rise in any of the communication costs will hamper economic activity and thus economic welfare - for this reason communication costs enter the denominator in the equation.

\footnotetext{
${ }^{9} \mathrm{~A}$ community need not be country, and is perceived here as relatively homogenous in term of the cognitive distance (Nooteboom 2000) of its members towards each other and in terms of the knowledge that is tacit.

${ }^{10}$ Therefore, this production function is strictly quasi-concave, while its isoquants are negatively sloped and strictly convex.
} 
It seems obvious to assume that an increase in any of the three communication costs will negatively affect social welfare. Hence indicating why these costs should be the denominator. Decoding communicated messages is proportional to the size of a population, but needs only to be done by the receiver of a message. On this Dudley $(1999$, p.602) further remarks that "the efficiency of markets depends on people's ability to negotiate and enforce contracts, output is decreasing in the cost, d, of decoding a unit of information. Owing to network effects, this transaction cost is offset by increases in the number of other people, $\mathrm{n}_{\mathrm{t}}-1$, with whom each individual can communicate." Due to the impact of knowledge on productivity, output, q, increases with the amount of information stored. The relation between $\mathrm{q}$ and storage cost (s) in inverse under competitive market conditions in particular. There is, furthermore, a direct link between the size of a population and the storage costs that need to be incurred. Transmission costs, tr, are not directly related to the size of a population; depending on circumstances (costs), a population of a given size can transmit knowledge extensively. If there are scale economies to joint production, for example because (co-) workers or partners need to be coordinated, however, increases in transmission costs will decrease q.

Usually, in reality, any development that affects one type of communication cost is likely also to affect other communication costs. A dynamic welfare perspective, for which some suggestions are brought forward in these pages, might suggest policy measures that violate the Pareto criterion. This would then be for different reasons than possible violations of the Pareto criterion that Pigou, for example, suggests. Pigou (1924, p.78) suggests for example that an income re-distribution from rich to the poor would be justifiable because that would allow "more intense wants to be satisfied". Indeed, for the dynamic welfare perspective suggested here utilitarian considerations play a less prominent role than in the Paretian view. How the suggested dynamic, Schumpeterian welfare perspective suggested here fits in Cowen's classification introduced at the start of this section is not clear. I would not present this approach as necessarily incompatible with the other three kinds, including a Paretian one.

\section{Changes in the System of IPR \& Welfare}

IPRs are central institutions in a knowledge economy. The relevant legal and technological changes are easily identified, even though not all of their effects are clear. Evaluating developments in IPRs from a 
perspective of their effects on the dynamics of an economy is entirely appropriate given the objectives for this part of the system of law. Indeed, the purpose of establishing IPRs is twofold: first to stimulate the creation of new (useful) knowledge, and, secondly, to stimulate its dissemination. As Levin et al. (1987) observed among others, however, the positive effects of the presence and extension of Intellectual Property Rights (IPRs) is often assumed to be self-evident. IPRs are believed to be beneficial for both the firm that has obtained them as well as for society as a whole. There is, of course, some discussion in academic circles about the effects of IPRs and how to evaluate these (cf. Towse \& Holzhauer 2002), but these are mostly in comparative-static Paretian terms. The duration and scope of patents is one such a topic. Even from this perspective, a disregard of IPRs need not hurt the innovating firm. Other means to protect ones innovations might be preferred (Levin et al. 1987), or network effects might better kick in urging the innovating firm to enforce its IPR position less (Takeyama 1994).

In what follows I will discuss a number of changes in particularly patent law and copyright law in terms of their effects on communications costs. The changes I discuss are not exhaustive, although they do include the most significant ones. Each of the changes in IPR discussed will have effects on all of the three communication costs. The breath of the system of IPR has grown over time, both by adding new IPRs, such as the law protecting legal rights in databases, or by extending existing laws, such as allowing for the protection under patent law of software or business models. In addition, the (statutory) limitations on the commercial exploitation of the knowledge developed have decreased in number. This is no mixed picture: IPRs have grown stronger over time. Especially in the past decade a number of noteworthy developments can be mentioned. Often, the development in the United States is followed by changes in Europe. In this article, the differences between the two legal systems (US and Europe) are not so much discussed as the similarities between the two. The purpose of the discussion here is thus to evaluate the potential effects of changes a system of IPRs and not so much an analysis of the systems as they exist in a way that is relevant for economists. ${ }^{11}$ In doing this, attention will be drawn to elements that are un- or undernoticed from a more standard welfare approach. From this perspective, too, the

\footnotetext{
${ }^{11}$ See Raskind (1998) and Kitch (1998). For a broad overview, see Towse \& Holzhauer (2002). For a theoretical economic justification for copyrights, see Landes \& Posner (1989); Hettinger (1989) provides a broader discussion of the rationales for copyrights.
} 
undesirable effects of IPRs in general and patents in particular have been noted. It is argued, for instance, to possibly distort the direction of technological change (Adams \& Encauoua 1994), possibly slow down technological progress (Takalo \& Kanniainen 2000), or possibly reduce incentives to compete in R\&D or in downstream product markets (Encaoua \& Hollander 2002). To reiterate, the discussion here about the dynamic welfare effects of changes in IPRs need not be perceived of as a substitute for a more mainstream economic, Paretian approach.

Following the US, Europe has now decided that software can be protected under patent law in addition to copyright law, under which it would be protected previously. The protection patent law offers is shorter than copyright law, but is more powerful. ${ }^{12}$ Copyright law protects the particular expression of an idea, while patent law protects the idea itself irrespective of the way in which it is expressed. As ideas can usually be expressed in more than one way, copyrights offer a weaker kind of protection than patents do. Copyrights do not need to be registered in most countries, albeit that registration may facilitate enforcement in some case, and is in force immediately after publication of the material. A patent needs to be filed and approved, involving a variety of expenses. ${ }^{13}$

The scope of patent law is most hotly debated at the moment, both in the US and in Europe, in relation to the question of whether business models and software should also be patentable in Europe as it is in the US. Does Amazon.com's patent for 'one-click shopping' not violate the requirement that a patent should involve a physical component and must involve an inventive step? It is true that software is often not clearly distinguishable from hardware, and the demand that a patent application should needs to constitute an inventive step might be difficult to uphold. Reneging on these requirements too easily might, however, give rise to rent-seeking behavior on the part of the producing firms. However, in this case there is only software involved, and the software ('cookies') had already been developed prior to the application by others. The particular business model is a useful invention, to be sure, but

\footnotetext{
${ }^{12}$ In 1998 in the US the duration copyrights last has increased from life of the author plus 50 years to life of the author plus 70 years, effective immediate. In that same year, again following Europe's example, the duration of patents has increased to 20 years, from 17 years, in the US.
} 
does it not unduly raise communications costs? Certainly it does for other firms who would like to use this method and now have to license it. In addition, the model also allows firms to increase the extent to which they may differentiate their products and discriminate their prices. The net result of the latter is likely to be that consumers suffer (Dolfsma 2004). The decision to extent the scope of patents to include living tissue is contested as well. Besides the moral aspects of the debate, there is the issue that the distinction between discovering and inventing, never entirely clear, is blurred to the extent that it no longer exists. The latter (invention) used to be a precondition for a patent to be granted. Patentability on living tissue might, but need not, have sped up the discovery of the exact shape of the human genome, for instance, but it will severely restrict the use to which that knowledge can be put for the coming years.

The duration of patents has increased too, most recently (1998) from 18 to 20 years in the US. The lengthening of the patent for pharmaceutical products is probably less problematic in this light, given the requirements these face before they are allowed on the market, although it does fit the general picture. Fisher (2001) provides a more extended discussion of the development in patent law and its effects on innovative activity.

Copyrights equally are extended in scope and duration; legal scholar Lawrence Lessig $(1999,2001)$ is among the more prominent people to lament this development. ${ }^{14}$ Most recently, the duration of copyrights in the US was lengthened from life of the author plus 50 years to life of the author plus 70 years, effective retrospectively. Several years ago both the US and Europe has started protecting databases as part of copyright laws. In the past a collection of 'brute facts' would not constitute a creative act and would thus not warrant protection, now a database is now protected (Maurer et al., 2001). The American Digital Milennium Copyright Act (DMCA, came into force 1998) as well as the European Directive on copyright (2000) prohibit agents from making available technical measures that

\footnotetext{
${ }^{13}$ OECD (1997) discusses some of the differences in the way in which patents are administered in the US vs Europe, as well as their implications.

${ }^{14}$ His is not a unique position among legal scholars (see Netanel 1996 a.o.) or among economists (see the collection edited by Towse \& Holzhauer 2002; in addition, see Stiglitz (1999).
} 
might be used to circumvent measures taken to protect copyrighted work (Koelman 2000). As these means can often also be used for other, legitimate purposes, this element of the new copyright law is much debated. It is also unclear what 'making available' means: does a scientist in the field of, e.g., cryptology presenting his work to fellow scientists make available a means to circumvent the technical protection (encryption) on copyrighted work? Encryption is also used to prevent consumers from making copies of work to be used in different regions of the world than their own. The world is divided into regions that each has different hardware specification, which disable software from one region to be recognized in another region. ${ }^{15}$ The cost to society seems evident as consumers are restricted in the consumption of something they have legally obtained (Dunt et al., 2002). Encryption is also being used to prevent consumers from playing a $\mathrm{CD}$ on a personal computer, making a copy for personal use, to share with family and close friends, or as a back-up. This increases storage costs especially.

The tendency to strengthen the protection offered by copyright law is also clear in the way in which it is enforced. A law can never spell out how exactly it should be applied, and perhaps it should not as a matter of principle. Therefore, judges when applying the law have room for their own interpretation, certainly in a Roman Law system but even in a Common Law system where leeway for a judge looking at a specific case is more limited by rulings given in other, similar cases. Considerations about the effect of enforcing copyrights for competition in a market are rarely aired - the different fields of law are quite separated even when one sees them conflict in reality, such as IPR clashing with antitrust law (Encaoua \& Hollander 2002; Dolfsma 2002b). An example is the ruling on Napster, where what is called in legal terms 'normal exploitation' of a work is extended to the full exploitation, covering the publication of a work in ways that were not foreseen at the time of the creation. Walt Disney could not have foreseen that his creation Mickey Mouse (formerly known as Steamboat Willey) would be published digitally and distributed over the Internet. Now this existing work is also protected under copyright law from distribution over the Internet. In actual fact, there is another catch to this court case against Napster. The court decided that existing players should first be allowed to develop a means

\footnotetext{
${ }^{15}$ There are 6 regions (Dunt et al. 2002). These are: (1) USA, Canada \& US territories; (2) Japan, Europe, South Africa \& Middle East; (3) South-East Asia; (4) Autralia, New Zealand, PNG, Pacific Islands, Central and South America; (5) Africa, Russia, Former Russian States, North Korea, East Asia; (6) China \& Tibet.
} 
by which to make music available in digital form legally, without limiting the time they could take. ${ }^{16}$ Copyright law is now no longer just a de facto entry barrier preventing possible entrants from moving into this market, it is a de jure one. How this constitutes an incentive for innovation is difficult to conceive. The tension between copyright law and anti-trust law -always there- mounts.

The developments listed above restrict the use of a legally acquired work by a consumer. Either directly or indirectly the limitation built into copyright law of 'fair use' is restricted by a combination of legal and technical means. ${ }^{17}$ At present, legal and technical developments are thus under way to make a 'strong' system of digital rights management (DRM) possible for copyright law. In addition to a strict enforcement of a strengthened copyright law, techniques such as encryption are required. The circumvention of the latter needs then to be prohibited by law as well. Even when these requirements are met, this paper suggests the question whether such a development would not raise communication cost to the extent that the public interest would be hurt, either directly or indirectly.

Relating the discussion about the development of IPRs to the different kinds of communications costs introduced in section 3 is quite straightforward. Indeed, communication costs increase in relative terms as a result of the full-scale application of IPRs to the knowledge economy, a result further shored up by the developments in the system of IPR itself. Decoding costs rise as a result of the technical measures to prevent copyrighted works from being copied, used in certain electronic equipment, or outside certain geographical boundaries. One need to acquire more information carriers than one would otherwise. Using available knowledge will become more expensive when the scope and duration of IPRs expand this basically relates to direct transmission costs (licenses), but also to costs that need to be born to find out if one tries to discover one would be violating another party's legal rights (Lessig, 2001). As the

\footnotetext{
${ }^{16}$ Court of Appeals for the Ninth Circuit, A\&M records, INC. vs. Napster, INC; see also Dolfsma (2002).

${ }^{17}$ For a discussion of the US 'fair use' principle (fair dealing in the UK), and its relation to similar limitations in continental European law -in the Roman Law tradition- see Alberdingk Thijm (1998). In brief, where the US proposes a procedure in continental Europe (the Netherlands) an exhaustive list of uses that copyright does not prohibit is drawn up. How computer code (software) can have effects on use that are in fact legal is discussed by Lessig (1999). Guibault (2002) discusses how contract law is used to obviate the limitations present in copyright so as to allow for an extended legal protection.
} 
development of knowledge is necessarily cumulative, such costs may be high and having to incur such costs will not be a stimulus for innovation. Storage costs rise as a consequence. The fact that transmission costs rise seems clear, certainly when discussing developments in the area of copyrights. For copyright law two central notions come into play: publishing and copying. Transmitting knowledge, either using an existing channel or using a new way of publishing material, becomes more expensive due to the developments discussed as the right holders' position has become stronger over the years. A rights holder can refuse to publish a work through a new means of communication. More kinds of works are protected, while the number of limitations to a legal position has been restricted, thus increasing transmission costs. This holds for transmission of knowledge protected under patent law as well, as circumstances under which a party would need to take a license proliferate. Unless the authorities impose a compulsory license when the public interest would demand it, the right holder can prevent the use by others of a particular piece of knowledge, implying a steep increase in transmission costs.

\section{IPR, Competition and Social Welfare}

Considering this discussion of the development of IPRs in light of the proposed dynamic welfare perspective developed in earlier session, one could claim with Stiglitz $(1999$, p.9) that "it is possible that an excessively 'strong' intellectual property regime may actually inhibit the pace of innovation”, and slow the pace of economic development. Such a conclusion hinges, of course, on the correct interpretation of the effects of developments in IPRs in terms of communication costs on innovative activity.

Economists would be interested in the effects of such developments on competition in a market too (Boldrin \& Levine 2002, Romer 2002). These effects are not always clear, and can perhaps be illustrated best by referring to the case of the music industry and the role copyrights play. ${ }^{18} \mathrm{~A}$ legal system's geographical boundaries are important to keep in mind - at least until a complete harmonization on all issues is realized across the globe. The geographical basis of copyright law is a de facto restriction of the relevant market, allowing firms to monitor each other's behaviour closely - 
indeed a game theoretic analysis shows that collusion is likely to occur (Klaes, 1997). In the oligopolistic market such as this one is, the outcome is an absence of competition on price (cf. Selten 1973).

It is Baumol (2002) who has argued forcefully that competition in a free market is to be regarded as the main cause for economic growth. His explanation is the creation, but most importantly the diffusion of knowledge that is best facilitated by the free market (see also Mokyr 2002). According to calculations by Baumol (2002), $80 \%$ of the economic benefits generated by innovations do not accrue to the parties directly or indirectly involved with the innovation. Extending the scope and duration of IPR should decrease that percentage in the conviction that creation of new knowledge is thus stimulated. This is premised on a number of beliefs that need not be true. These (often incorrect or incomplete) views include:

- Innovators are motivated by monetary / material rewards only ${ }^{19}$;

- Creative individuals possess the rights in their creations and will thus receive the reward;

- IPRs are the best means to reward creative individuals materially ${ }^{20}$;

- It is always, or at least in most cases, in the best interest of rights holders to diffuse the knowledge (or the products which embody them) as much as possible once they have obtained IPR protection.

The latter issue about the inclination to diffuse newly developed knowledge, stimulated by the system of IPRs relates to the matter of what circumstances stimulate economic growth. Does allowing innovators a larger share of the economic pie stimulate innovation and economic growth such that in absolute (even if not in relative) terms everybody's pie is larger, or is it a zero-sum game? The matter relates directly to a governments' goal of the public good and if that is best served by enforcing IPRs. The argument as

\footnotetext{
${ }^{18}$ Indeed, the existing business model of firms in the music industry is predicated on the existence of copyrights (Huygens et al. 2001, Dolfsma 2000).

${ }^{19}$ See Hui \& Png (2002), or Frey (1997) and Le Grand (2003) for a more general argument.
} 
suggested in Section 3 particularly is that the dynamic effects are more important in such considerations than the static, distributive ones.

How may one evaluate the developments in a set of institutions that may be considered among the more important for a knowledge economy from the perspective of a dynamic (Schumpeterian) welfare theory? As knowledge is often communicated as information, the characteristics of information goods are important to note. The well-known characteristics of such goods and the markets they are exchanged on (Dolfsma 1998) entail that a full scale application of IPRs in a knowledge economy is itself a de facto strengthening of IPRs, and certainly to the extent that the knowledge economy is a digital one (Stiglitz, 1999). Stiglitz (1999, p.10) holds that information goods generate more positive externalities than physical goods. While the social returns to innovation are much bigger than the private ones in general (Jones \& Williams 1998), the creation of new information good (knowledge) would in this line of reasoning serve the public interest even more. In terms of the relation between the public and the private realm, the latter expands because of this.

\section{Conclusion}

A knowledge-based economy needs a welfare theory that is able to grasp and evaluate its dynamics. In this short article, I have taken suggestions from Schumpeter for a dynamic welfare economics and developed some ideas for a dynamic (Schumpeterian) welfare economics. These ideas acknowledge the role of (increases in the) knowledge (base) for an economy. I distinguish storage, decoding and transmission costs related to communication of knowledge, to indicate that an increase in one will lower social welfare. In a final section I have looked at recent development is IPR and evaluated them in the dynamic welfare terms, to suggest that the strengthening of IPRs is debatable from the perspective of the public interest. As knowledge develops cumulatively in direct interactions between people, and is not simply available off the shelve where it winds up like manna from heaven to be put to use freely, the costs of communication has a strong impact on the diffusion of knowledge and the social welfare of a country. Changes in IPRs we are experiencing now increase the costs of communication and could

\footnotetext{
${ }^{20}$ However, see Shavell \& van Ypersele (2001); see Dolfsma (2000) for some information on the actual highly
} 
therefore be a potential impediment for the dynamics of the economy and for social welfare. The conclusion drawn by Romer (1993, p.66) that an economics of ideas requires "a policy of openness with few distortions" would thus find support.

skewed nature of the distribution of royalties among musicians. 


\section{Referenties:}

W.J. Adams and D. Encaoua (1994) "Distorting the direction of technological change" European Economic Review 38: 663-673.

D.B. Audretsch (1998) "Agglomeration and the Location of Innovative Activity" Oxford Review of Economic Policy 14(2): 18-29.

W.J. Baumol (2002) The free-market innovation machine: analyzing the growth miracle of capitalism. Princeton UP, Princeton, NJ

M. Blaug (2001) “Is Competition Such a Good Thing? Static versus Dynamic Efficiency” Review of Industrial Organization 19: 37-48.

---- (1980) The Methodology of Economics. Cambridge.

M. Boldrin \& D. Levine (2002) “The case against intellectual property” American Economic Review 92(2): 209212 .

M. Casson (1997) Information and Organization - A new perspective on the theory of the firm. Oxford: Clarendon Press.

R. Cowan, P. David and D. Foray (2000) "The Explicit Economics of Knowledge Codification and Tacitness" Industrial and Corporate Change 9(2): 211-253.

T. Cowen (2000) "Introduction" in: T. Cowen (ed.) Economic Welfare. Cheltenham: Edward Elgar, pp. xiii-xviii. Denison, E.F. (1967) Why Growth Rates Differ. Washington, DC: The Brookings Institute.

Denzau, A.T. and North, D.C. (1994) “Shared Mental Models: Ideologies and Institutions”, Kyklos 47: 3-31.

W. Dolfsma (1998b) “Internet: An Economist’s Utopia?” Review of International Political Economy 5(4).

----, (2000) How Will the Music Industry Weather the Globalization Storm? First Monday 5(5) May, www.firstmonday.org.

----, (2001) "Metaphors of Knowledge in Economics” Review of Social Economy 59(1).

----, (2002) "The mountain of experience: how people learn in a complex, evolving environment" International Journal of Social Economics, 29(8): 675-684

----, (2002b) "Napster \& KaZaA: Copyright \& Competion" IER - Intellectueel Eigendom en Reclamerecht 18(4): 178-180.

----, (2004) “The Logic of Collective Consuming: Consumers as Subcontractors on Electronic Markets” International Journal of Social Economics, 31(8).

L. Dudley (1999) “Communication and Economic Growth” European Economic Review 43.

E. Dunt, J.S. Gans en S.P. King (2002) “The economic consequences of DVD regional restrictions” Economic Papers 21(1): 32-45.

D. Encaoua and A. Hollander (2002) “Competition Policy and Innovation" Oxford Review of Economic Policy 18(1): 63-79.

W. Fisher (2001) "Intellectual Property and Innovation: Theoretical, Empirical, and Historical Perspectives," in Industrial Property, Innovation, and the Knowledge-based Economy, Beleidsstudies Technologie Economie, Vol. 37 (2001).

B.S. Frey (1997) Not Just for the Money - An Economic Theory of Personal Motivation. Cheltenham: Edward 
Elgar.

O. Granstrand (1999) The Economics and Management of Intellectual Property. Edward Elgar, Cheltenham.

L. Guibault (2002) Copyright Limitations and Contract. Amsterdam, proefschrift, Instituut voor InformatieRecht.

V. Gurbaxani, N. Melville and K. Kraemer (2000) "The production of Information Services: a firm-level analysis of information systems budgets" Information Systems Research 11(2): 159-176.

M. Hansen (1999) "The Search-Transfer Problem: the role of weak ties in sharing knowledge across organizational subunits" Administrative Science Quarterly 44(1): 82-111.

E.C. Hettinger (1989) “Justifying Intellectual Property" Philosophy and Public Affairs 18(1): 31-52.

K.-L. Hui \& I.P.L. Png (2002) “On the Supply of Creative Work: Evidence from the movies” American Economic Review 92(2): 217-220.

Huygens, M., C. Baden-Fuller, F.A.J. Van Den Bosch and H.W. Volberda (2001) "Co-evolution of Firm Capabilities and Industry Competition: Investigating the Music Industry, 1877-1997” Organisation Studies 22(6): 971-1011.

C. Jones \& J. Williams (1998) "Measuring the Social Returns to R\&D” Quarterly Journal of Economics 113(3): 1119-1135.

E.W. Kitch (1998) "Patents" in: P. Newman (ed.) The New Palgrave Dictionary of Economics and Law, Vol. 3, Macmillan, London, pp. 13-17.

M. Klaes (1997) "Sociotechnical constituencies, game theory and the diffusion of the compact disc" Research Policy 25: 1221-1234.

K. Koelman (2000) "A Hard Nut to Crack: The Protection of Technological Measures" European Intellectual Property Review 2000, p. 272-288.

Landes, W.M. and R.A. Posner. “An Economic Analysis of Copyright Law.” Journal of Legal Studies 18 (June ” 1989): 325-363.

J. Le Grand (2003) Motivation, Agency, and Public Policy. New York: Oxford UP.

L. Lessig (1999) Code and other Laws of Cyberspace. Basic Books, New York.

L. Lessig (2001) The Future of Ideas - The fate of the commons in a connected world. Basic Books, New York.

B. Lev (2001) Intangibles - Management, Measurement and Reporting. Brookings Institute Press, Washington, D.C.

R. Levin, A. Klevorick, R. Nelson \& S. Winter (1987) “Appropriating the Returns from Industrial Research and Development" Brookings Papers on Economic Activity 3.

Levinthal, D.A. (1998) "The slow pace of rapid technological change. Gradualism and Punctuation in Technological Change." Industrial and Corporate Change 7(2), 217-247.

S.M. Maurer, B. Hugenholz, en H.J. Onsrud (2001) “Europe's Database Experiment” Science 294 (26 October), p. 789-790.

P. Milgrom and J. Roberts (1988) "Communication and Inventory as Substitutes in Organizing Production" Scandinavian Journal of Economics 90(3): 275-289.

E.J. Mishan (1960) “A survey of welfare economics” Economic Journal 70(278): 197-265.

J. Mokyr (2002) The Gifts of Athena - Historical Origins of the Knowledge Economy. Princeton UP, Princeton, NJ.

R.R. Nelson (2004) "The market economy, and the scientific commons" Research Policy 33, forthcoming. --- (1990) “Capitalism as an engine of growth" Research Policy 19: 193-214. 
---- (1981) “Assessing private enterprise: an exegesis of tangled doctrine” The Bell Journal of Economics12(1): 93-111.

---- (1959) “The simple economics of basic scientific research" Journal of Political Economy 67: 297-306.

N.W. Netanel (1996) "Copyright and a Democratic Civil Society" Yale Law Review 106(283).

B. Nooteboom (2000) Learning and Innovation in Organizations and Economies. Oxford: Oxford UP.

Organisation for Economic Co-operation and Development (1996) Employment and growth in the knowledgebased economy. Paris : OECD

Organisation for Economic Cooperation and Development (1997) Patents and Innovation in the International Context. OESO, Parijs.

L.J. Raskind (1998) "Copyright” in: P. Newman (ed.) The New Palgrave Dictionary of Economics and Law. Macmillan, London, pp. 478-483.

P. Romer (2002) "When should we use intellectual property rights?" American Economic Review 92(2): 213-6.

----, (1994) "New goods, old theory, and the welfare costs of trade restrictions" Journal of Development

Economics 43: 5-38.

----, (1993) “Two Strategies for Economic Development: Using Ideas and Producing Ideas" Proceedings of the World Bank Annual Conference on Development Economics 1992. IBRD/World Bank

----, (1987) “Increasing Returns and Long-Run Growth” Journal of Political Economy 94(5).

N. Rosenberg (1990) "Why do firms do basic research (with their own money)?" Research Policy 19: 165-174. Saxenian, A., 1994, Regional Advantage, Cambridge (MA), Harvard University Press.

J. Schumpeter, J. (1943 [1952]) Capitalism, Socialism and Democracy, Allen \& Unwin, London.

R. Selten (1973) “A simple model of imperfect competition” International Journal of Game Theory.

A. Shaikh (1990) "Humbug Production Function" in: The New Palgrave.

C. Shapiro \& H. Varian (1999) Information Rules. Harvard Business Review Press, Boston, MA.

S. Shavell \& T. van Ypersele (2001) "Rewards versus Intellectual Property Rights" Journal of Law and Economics 44(2): 525-47.

J. Stiglitz (1999) Public Policy for a Knowledge Economy. Department for Trade and Industry \& Center for Economic Policy Research, London.

T. Takalo and V. Kanniainen (2000) "Do patents slow down technological progress? Real options in research, patenting, and market introduction" Internation Journal of Industrial Organization 18: 1105-1127.

L.N. Takeyama (1994) "The welfare implications of unauthorized reproduction of intellectual property in the presence of demand network externalities" Journal of Industrial Economics 42(2): 155-166.

R. Towse en R. Holzhauer (2002, eds.) The Economics of Intellectual Property. Edward Elgar, Cheltenham, 4 volumes.

G. van der Panne and W. Dolfsma (2003) "The Odd Role of Proximity in Knowledge Relations - High-tech in the Netherlands" Journal of Economic and Social Geography 94(4): 453-462.

J. Vickers (1995) “Concepts of competition” Oxford Economic Papers 47(1): 1-23. 
Figure 1: Different Learning Paths
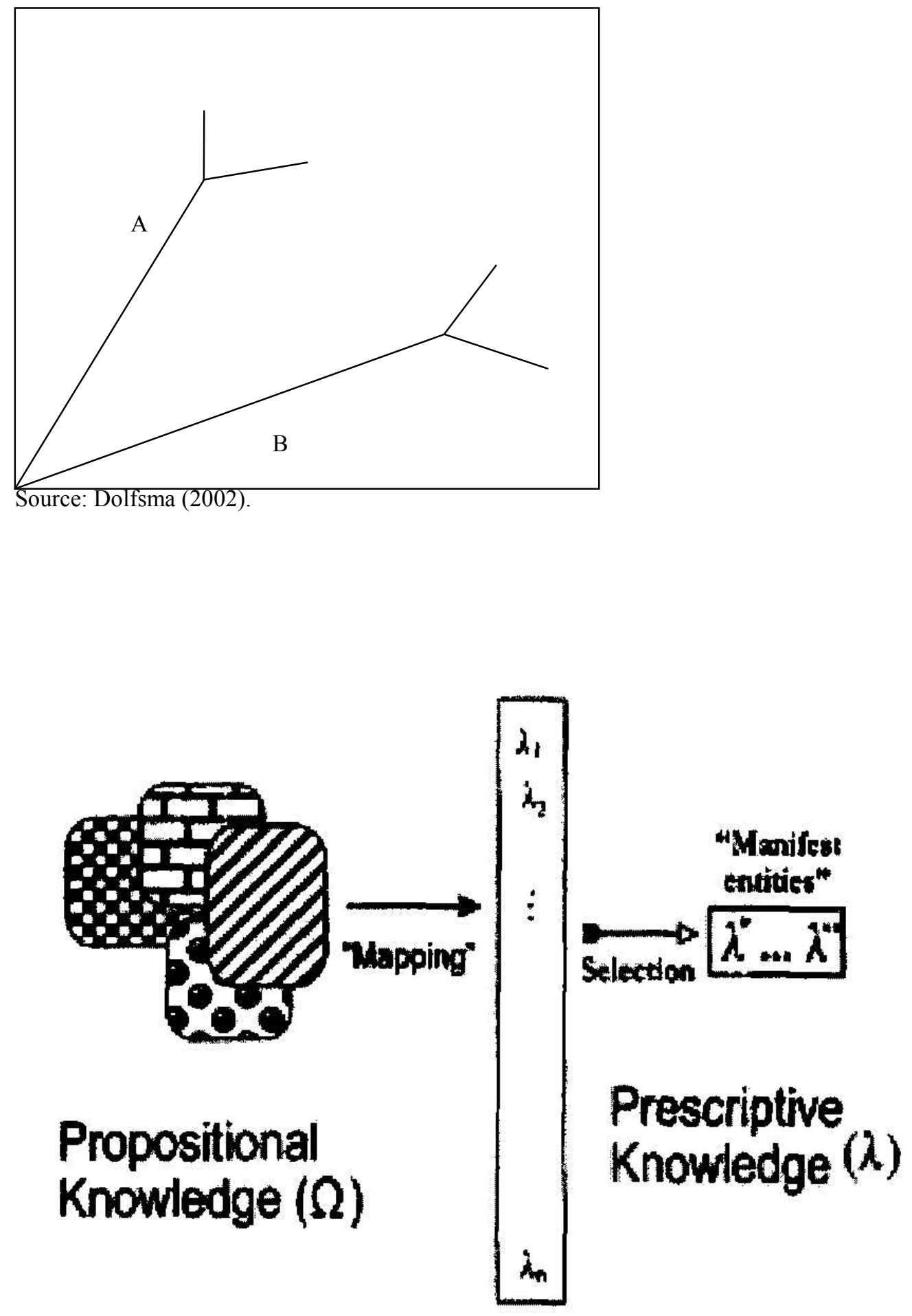

Feasible

Techniques

Figure 2: Types of Knowledge; Source: Mokyr (2002, p.17). 


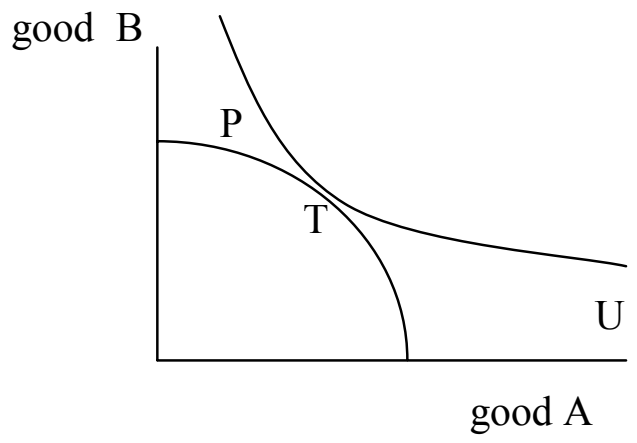

Figure 3: Paretian Welfare

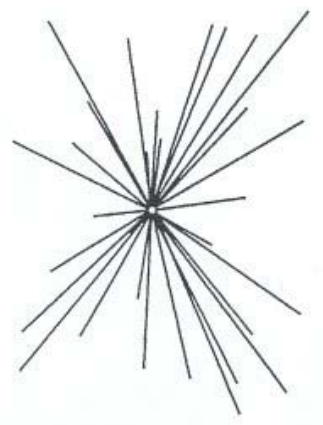

(a) Centralized

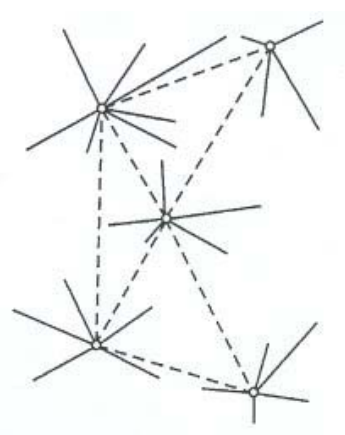

(b) Docentralised

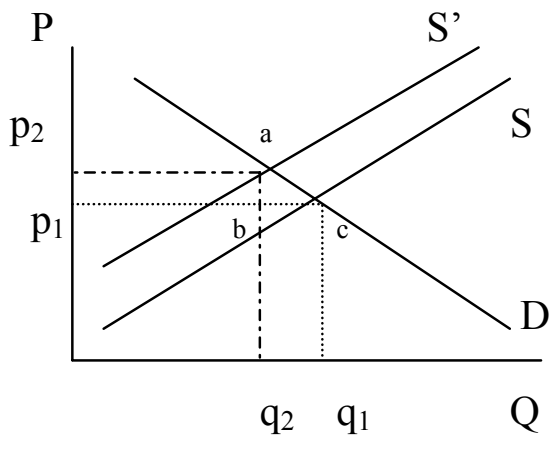

Figure 4: Welfare Triangles

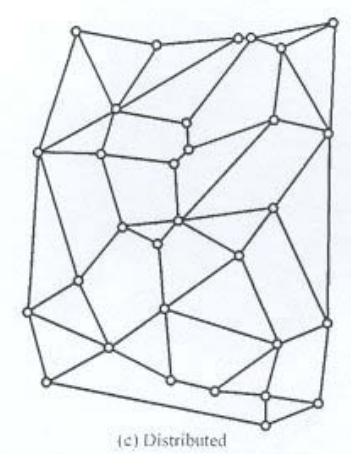

Figure 5: Communication structures; Source: Dudley (1999) 
Table 1: Communication \& Communication Costs

\begin{tabular}{|c|c|c|c|c|}
\hline \multirow[b]{2}{*}{ Costs of: } & \multicolumn{4}{|c|}{ Communication } \\
\hline & None & Centralized (a) & Decentralized (b) & Distributed (c) \\
\hline Transmission & High & Low & Low & Low \\
\hline Storage & High & High & Low & Low \\
\hline Decoding & High & High & High & Low \\
\hline
\end{tabular}




\section{Publications in the ERIM Report Series Research* in Management}

\section{ERIM Research Program: "Organizing for Performance"}

\section{4}

Learning And Governance In Inter-Firm Relations

Bart Nooteboom

ERS-2004-003-ORG

http://hdl.handle.net/1765/1122

Organisational Learning And Multinational Strategy

Bart Nooteboom

ERS-2004-004-ORG

$\underline{\text { http://hdl.handle.net/1765/1123 }}$

Density And Strength Of Ties In Innovation Networks: A Competence And Governance View

Bart Nooteboom and Victor A. Gilsing

ERS-2004-005-ORG

http://hdl.handle.net/1765/1124

Innovation, learning and cluster dynamics

Bart Nooteboom

ERS-2004-006-ORG

http://hdl.handle.net/1765/1125

Empirical Tests Of Optimal Cognitive Distance

Stefan Wuyts, Massimo G. Colombo, Shantanu Dutta, and Bart Nooteboom

ERS-2004-007-ORG

http://hdl.handle.net/1765/1126

Entrepreneurship in Transition: Searching for governance in China's new private sector

Barbara Krug and Hans Hendrischke

ERS-2004-008-ORG

http://hdl.handle.net/1765/1128

Exploring Emotional Competence: Its effects on coping, social capital, and performance of salespeople Willem Verbeke, Frank Belschak and Richard P. Bagozzi

ERS-2004-014-ORG

http://hdl.handle.net/1765/1174

The Impact of Business Ownership Change on Employee Relations: Buy-outs in the UK and the Netherlands Hans Bruining, Paul Boselie, Mike Wright and Nicolas Bacon ERS-2004-021-ORG

http://hdl.handle.net/1765/1263

* A complete overview of the ERIM Report Series Research in Management: https://ep.eur.n//handle/1765/1

ERIM Research Programs:

LIS Business Processes, Logistics and Information Systems

ORG Organizing for Performance

MKT Marketing

F\&A Finance and Accounting

STR Strategy and Entrepreneurship 